Send your letters to the Editor,

British Dental Journal,

64 Wimpole Street

London

W1G 8YS

Email bdj@bda.org

Priority will be given to letters less than 500 words long.

Authors must sign the letter, which

may be edited for reasons of space.

\section{MALIGNANT SUSPICION}

Sir, a 69-year-old gentleman was referred to us by his GP complaining of swelling under his eye for six weeks that had been increasing in size. He also described a lump in the palate which had developed ten days prior to presentation at the clinic and which was now getting bigger. He had an associated facial swelling. There was no visual disturbance, no pain and no paraesthesia. Six months earlier he had a left nephrectomy due to renal cell carcinoma (RCC). Clinical examination ruled out a dental cause. A CT scan showed a large soft tissue mass centred on the right maxillary antrum extending superiorly to involve the floor of the orbit and posteriorly to involve the right infero-temporal fossa, medially to involve the ethmoid air cells and nasal cavity. An incisional biopsy of the maxilla showed RCC metastasis. RCC is the third most common cause of distant metastases to the head and neck region. ${ }^{1}$ In patients with a known history of RCC, it is therefore necessary to regard head and neck lesions with a high index of suspicion for malignancy. ${ }^{2}$

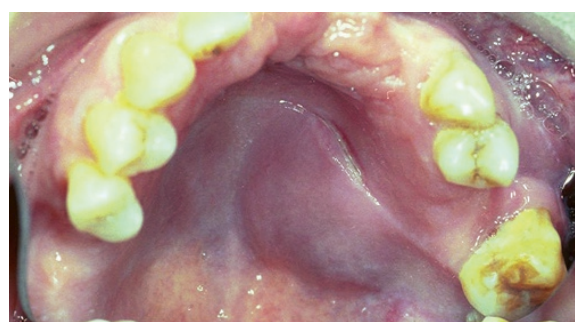

Fig. $115 \mathrm{~mm}$ soft, raised, left palatal lesion

I. Al-Hadad, S. Kotecha, P. Praveen, S. Parmar By email

1. Chhabra P, Bhatt V, Brown A M. Metastatic renal cell carcinoma in the neck: an unusual presentation. Dent Update 2009; 36: 511-513.
2. Pompeo A C, Kanashiro H, Silva M. Renal cell carcinoma presenting as a cervical mass. Int Braz J Urol 2005; 31: 151-152.

DOI: 10.1038/sj.bdj.2010.212

\section{MALOCCLUSION CHALLENGE}

Sir, to rationalise and defend the foundations of our beliefs is part of everyday modern life and very much part of science. Indeed the entire rational scientific method is based on a willingness to review and correct errors, and to accept challenges to what is already known. Nearly a million people in Britain are treated with orthodontics every year without a clear understanding of what is causing the problem, meaning the treatment is not based on the cause. It is only through science that we have a chance of finding the truth, this is what makes it so valuable.

In an editorial last year (A black swan; $B D J$ 2009; 206: 393) I invited the orthodontic community to join a debate on the aetiology of malocclusion. The editorial elicited two responses.

The first was from Dr G. D. Singh ( $B D J$ 2009 ; 207: 52-53) who felt that the suggestion that the length of the mandible is under tight genetic control was 'ostensibly erroneous' and considers it possible even in an adult to 'show a tendency for renewed mandibular growth', which I would agree with but feel that there is little evidence for. And the second by $\mathrm{Dr}$ G. McIntyre (Déjà vu; BDJ 2009; 207: 97) who failed to 'see the logic in Dr Mew's article that the universities should prove his theories right or wrong', I feel that the universities have a duty to follow scientific procedure and seek the truth.

Since then I have approached the British Orthodontic Society who have argued against the need to hold such a debate and the GDC who have declined to repeat the debate that they held on this very subject in 1936 or discuss the situation further.

I feel that these esteemed professional bodies have shown an aversion to openness and a dismissive reaction to my scepticism that is not scientific. By avoiding rational debate the profession are betraying more than the integrity of their discipline, they are devaluing the science that they claim to uphold. Everything must be open to challenge, and I repeat mine inviting the orthodontic profession to a debate to test the hypothesis that 'malocclusion is caused by the environment and modified by the genes'. Who will accept this challenge?

M. Mew

DOI: 10.1038/sj.bdj.2010.213

\section{THERAPIST WOES}

Sir, I am a dual qualified dental hygienist-therapist. I have been searching for full-time employment over the past two years with no success. I recently scraped the barrel and went to work part-time for a corporate dental company which advertises on the local and national job sites on a regular basis.

I was paid $45 \%$ of my daybook. Most days, I would be lucky if even half of my day was booked up. I was left with no nurse and was expected to do the full-time job of the dental nurse that I should be provided with. In addition to this, there was no functioning ultrasonic scaler in my surgery. When I mentioned this and explained that having no ultrasonic scaler made my job more difficult, I was simply told that 'manually scaling' teeth was the 'preferred method' of scaling!

I am no longer working for this company as I felt I could not provide the 
quality of healthcare that my patients deserved. These corporate dental companies appear to have tapped into the vast 'pool' of overseas dentists, the majority of whom unfortunately are not familiar with NHS, GDC and NICE guidelines. Most patients who spoke to me complained that they were not happy with the service and treatment that they had received from their dentist and as a result left the practice. This happened almost on a daily basis. In my opinion, corporate dental companies are ruining both the reputation and business of dentistry in the UK.

I am currently working one and a half days a week as a dental therapist. Apart from the same corporate dental company, there are no employers locally advertising for dental hygienist-therapists. After typing this letter, next on my 'to do' list is to fill out an application form for the local supermarket to try and fill the rest of my week so I can keep the roof over my head and support family.

\section{H. Griffiths}

By email

DOI: 10.1038/sj.bdj.2010.214

\section{IOM AWARENESS}

Sir, I should like to share with your readers the efforts of Dentaid, the oral health charity, to promote its 'Action against Infant Oral Mutilation' (IOM). Village healers usually carry out this traditional practice, prevalent in DR Congo, Ethiopia, Kenya, Somalia, Sudan, Tanzania and Uganda.

If an infant is suffering from diarrhoea, vomiting or fevers, the healer will tell the mother that the child has "tooth worms' which must be removed or the child may die. These 'tooth worms' are the unerupted tooth buds, usually of the lower canines, which then are prised out of the gum using unsterile tools such as a bicycle spoke, a nail or knife, without anaesthesia.

The resulting blood loss and shock can lead to anaemia; the unhygienic methods can cause septicaemia, tetanus and/or HIV/AIDS and can on occasions be fatal. Long-term effects can include eradication and/or malformation of other primary and permanent teeth in the area.

Dentaid has formed an Action Group to formulate strategies to address this practice and an Information Leaflet has been produced to raise awareness of IOM amongst governments, dental schools, health professionals, teachers and charity workers in Africa and in countries such as the UK in which immigrants settle.

Further information about IOM can be obtained from www.dentaid.org (click on Overseas Projects) and the Information Leaflet may be downloaded as a PDF file.

If any of your readers have connections with charities or health personnel working in these countries and would like copies of this leaflet to pass on to them, these are available free of charge from Dentaid. Please email me at rosemary@dentaid.org with your details and the quantity required.

R. Longhurst Exmouth

Dentaid Action Group Member DOI: 10.1038/sj.bdj.2010.215

\section{PAPER CLIP IMPLANT}

Sir, I thought the attached radiograph might be of some interest to the wider profession. The 'paper clip' design implant was placed with a 'hammer and chisel' (patient's description!) when the patient was 18 , now 48 . The conventional implant was placed three years ago. Both are rock solid.

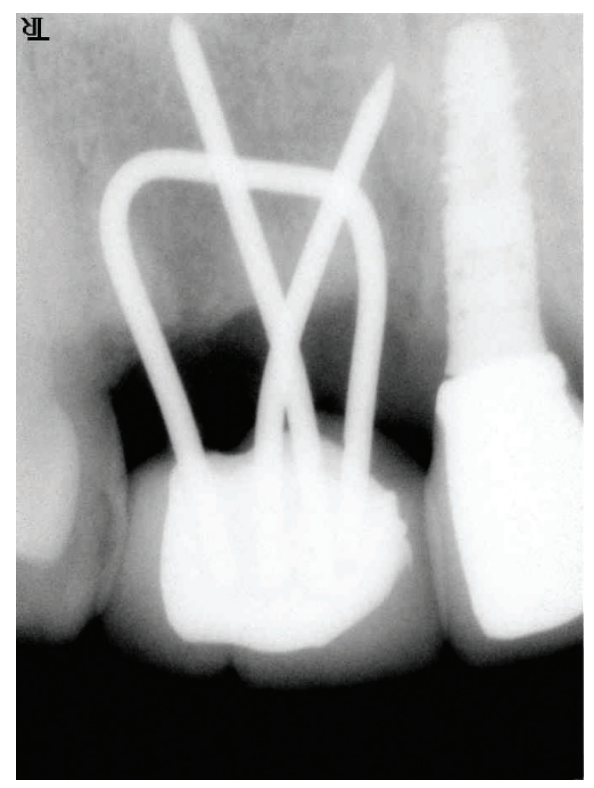

Fig. 1 Implants old and new

S. Bazlinton By email DOI: 10.1038/sj.bdj.2010.216 